\title{
Molecular Detection of Plasmid-Mediated Quinolone Resistance in Ciprofloxacin-Resistant Escherichia coli from Urine of Patients attending Garki Hospital, Abuja, Nigeria
}

\author{
Moses Oghenaigah Eghieye, Istifanus Haruna Nkene, Rejoice Helma Abimiku, Yakubu Boyi Ngwai, \\ Ibrahim Yahaya and Stephen Kadarko Parom
}

\section{ABSTRACT}

Urinary tract infections (UTIs) caused by Escherichia coli $(E$. coli) is common worldwide; and its successful treatment using antibiotics is limited by acquisition of resistance by the bacteria. This study investigated the occurrence of plasmid-mediated quinolone resistance (PMQR) genes in ciprofloxacinresistant $E$. coli from urine of patients with suspected cases of UTIs attending Garki Hospital Abuja (GHA), Nigeria. A total of 8 confirmed ciprofloxacinresistant $E$. coli was screened for carriage of PMQR genes using polymerase chain reaction (PCR) method. The occurrences of the PMQR genes detected were in the order: $a a c-\left(6^{\prime}\right)-I b-c r(87.5 \%)>q n r B(50.0 \%)>q n r S(37.5 \%)>$ $o q x A B(12.5 \%)>q n r A(0.0 \%)$. qnrB and $q n r S$ did not exist alone, but in combination with other genes; $a a c-\left(6^{\prime}\right)-I b-c r$ existed both alone and in combination with others; the most prevalent patterns of existence were aac- $\left(6^{\prime}\right)$ $I b-c r$ alone and $a a c-\left(6^{\prime}\right)-I b-c r+q n r B+q n r S$ at $\mathbf{2 5 . 0 \%}$ each. This study has shown that the ciprofloxacin-resistant $E$. coli harbored $a a c-\left(6^{\prime}\right)-I b-c r, q n r B$, $q n r S$ and $o q x A B$ PMQR genes, with $a a c-\left(6^{\prime}\right)-I b-c r$ being the most prevalent. The genes were present either alone or in combination with one another. This has implication for the clinical application of fluoroquinolones to treat UTI in the study location and environs.

Keywords: Antibiotic, Escherichia coli, hospital, molecular, plasmid-mediated.
Published Online: August 5, 2020
IssN: 2684-5199
DoI :10.24018/ejbio.2020.1.4.60
M. O. Eghieye
Department of Microbiology, Nasarawa
State University, Keffi, Nigeria.
(e-mail: eghieyem @gmail.com)
I. H. Nkene
Department of Microbiology, Nasarawa
State University, Keffi, Nigeria.
(e-mail: nkeneharuna@gmail.com)
R. H. Abimiku
Research Department, Plateau State
Human Virology Research Centre
(PLASVIREC) Jos, Nigeria.
(e-mail: rejoiceafrica40@gmail.com)
S. K. Parom
Department of Pharmaceutics and
Industrial Pharmacy, Kaduna State
University, Kaduna State, Nigeria.
(e-mail: steveparom@gmail.com)
I. Yahaya
Department of Microbiology, Nasarawa
State University, Keffi, Nigeria.
(e-mail: yibrahim04@gmail.com)
Y. B. Ngwai*
Department of Microbiology, Nasarawa
State University, Keffi, Nigeria.
(e-mail: ngwaiyb@yahoo.com)
*Corresponding Author
(e)

indications in human or veterinary medicine has led to the development of bacterial resistance to quinolones over time [2]. Fluoroquinolone-resistance in gram-negative bacteria is in fact a global issue [6].

Bacterial resistance to quinolones results from: mutations in genes encoding DNA gyrase (gyrA and gyrB) and topoisomerase IV (parC and parE) associated with the quinolone-resistance determining regions (QRDRs); carriage of the plasmid-mediated quinolone resistance (PMQR) genes; and reduced accumulation of drugs or chemicals due to active efflux pump activity [6]-[8]. 
Plasmid-mediated quinolone resistance, which has been reported in clinical and environmental isolates around the world, appears to be spreading [9], [10]. Plasmid-mediated quinolone resistance was first reported in 1998 in the United States in a multi-resistant urinary Klebsiella pneumoniae that could transfer low level resistance to nalidixic acid, ciprofloxacin, and other quinolones to a variety of gramnegative recipients [1]. However, PMQR is now being reported in other gram-negative as well as and gram-positive bacteria [10].

Three mechanisms of PMQR have been discovered. First, it was shown to be encoded by $q n r$ gene, later named $q n r A$, as other distantly related $q n r$ determinants (namely $q n r B, q n r C$, $q n r D$, qnrS and $q n r V C$ ) were found which code for proteins of the pentapeptide repeat family that protects DNA gyrase and topoisomerase IV from quinolone inhibition [9], [10]. The second plasmid-mediated mechanism involves acetylation of quinolones with an appropriate amino nitrogen target (such as ciprofloxacin and norfloxacin) by $a a c\left(6^{\prime}\right)-I b$-cr gene encoding a variant of the common aminoglycoside acetyltransferase, AAC $\left(6^{\prime}\right)-I b-c r ;$ the third mechanism is enhanced efflux produced by plasmid genes qepA and $o q x A B$ for pumps QepA and $\mathrm{Oqx} A B$ respectively [10].

Plasmid-mediated quinolone resistance in E. coli has been reported globally [11]-[17]. In Nigeria, few reports on PMQRs are available [18], [19]. However, no specific report is available on the study area. This study therefore, investigates the occurrence of PMQR genes in ciprofloxacin-resistant $E$. coli isolated from the study location to provide a possible basis for the presence of the observed ciprofloxacin resistance. This study has far reaching implication as fluoroquinolones are drugs of choice for the treatment of urinary tract infections, of which $E$. coli is a common etiological agent.

\section{MATERIALS AND METHODS}

\section{A. Bacterial Isolates}

Eight confirmed ciprofloxacin-resistant E. coli (CREC) isolated from urine of patients with suspected UTIs attending Garki Hospital Abuja, Nigeria (GHA) were screened in this study. The isolates, which were obtained from a recent study [20], have antibiotic resistance profiles as shown in Table 1. The isolates were maintained on nutrient agar (Oxoid Ltd, Basingstoke, UK) slants at $4^{\circ} \mathrm{C}$ Refrigerator/Freezer (Model PRN 1313 HCA, BEKO, Germany); and sub-cultured on MacConkey agar (Oxoid Ltd, Basingstoke, UK) at $37^{\circ} \mathrm{C}$ for 24 $\mathrm{h}$ to obtain pure colonies before use in experiments.

\section{B. DNA Extraction}

The DNA of the isolates was extracted using boiling method as described by [21]. Briefly, following the purification, one pure colony of the ciprofloxacin resistant isolates, was inoculated into $2 \mathrm{ml}$ of Luria-Bertani (LB: Oxoid Ltd., Basingstoke, UK) broth and incubated at $37^{\circ} \mathrm{C}$ for $18 \mathrm{~h}$. Exactly $200 \mu \mathrm{l}$ of the LB culture was then transferred into Eppendorf tube and centrifuged in a microcentrifuge (Model 5417R:
Touch plate Super Mixer, CAT. No. 1291, Lab-line Instrument Inc., USA) at room temperature at $3200 \mathrm{rpm}$ for $2 \mathrm{~min}$. The supernatant was discarded leaving the cells in the tube. The cells were washed twice with washing buffer. Exactly $0.5 \mathrm{ml}$ of sterile phosphate buffer was added to the pellet and vortexed for $5 \mathrm{sec}$. It was then heated at $90^{\circ} \mathrm{C}$ for $10 \mathrm{~min}$. It was then cooled down rapidly by freezing for $10 \mathrm{~min}$. It was then centrifuged at $3200 \mathrm{rpm}$ for $1 \mathrm{~min}$ to separate the DNA and the cells debris. $300 \mu \mathrm{l}$ of the supernatant containing the DNA was then transferred into $2 \mathrm{ml}$ Eppendorf tube and stored at $-10^{\circ} \mathrm{C}$ for further use.

\section{Amplification of Target Genes}

The DNA amplification of target PMQR genes in the CREC isolates was carried out using singleplex PCR method by modification of the method earlier described by [21] using primers with sequences and expected amplicon sizes for each gene as listed in Table 2. Briefly, the reaction was carried out in $25 \mu \mathrm{l}$ reaction volume in artificial tubes which is made up of $5 \mu \mathrm{l}$ master mix, $2.4 \mu \mathrm{l}$ primer $(0.4 \mu \mathrm{l}$ each of forward and reverse primers), $0.5 \mu \mathrm{l}$ of $\mathrm{MgCl}_{2}$ (Sigma Chemicals, England), $1.5 \mu \mathrm{l}$ of DNA template and $15.6 \mu \mathrm{l}$ of nuclease-free water. The reaction tubes were placed in the holes of the thermo cycler (Model TC-312, Techne, England) and its door was closed. The oqxA, oqxB, qnrA, qnrB, and qnrS genes were amplified under the following conditions: Initial denaturation at $94^{\circ} \mathrm{C}$ for $5 \mathrm{~min}$ followed by 32 cycles of amplification at $94^{\circ} \mathrm{C}$ for $45 \mathrm{sec}$ each, annealing at $53^{\circ} \mathrm{C}$ for $45 \mathrm{sec}$, with final extension at $72^{\circ} \mathrm{C}$ for 5 min.

The amplification condition for detection of $a a c-\left(6^{\prime}\right)-I b-c r$ gene was carried out as follows: initial denaturation at $95^{\circ} \mathrm{C}$ for $5 \mathrm{~min}$, annealing at $59^{\circ} \mathrm{C}$ for $40 \mathrm{sec}$ and initial extension at $70^{\circ} \mathrm{C}$ for $30 \mathrm{sec}$ and with final extension at $72^{\circ} \mathrm{C}$ for $5 \mathrm{~min}$ [21].

\section{Agarose Gel Electrophoresis of Amplified Genes}

The amplified genes were separated on $1.5 \%$ agarose gel in agarose gel electrophoresis at $12.0 \mathrm{~V}$ for $20 \mathrm{~min}$. The separated genes were observed under U-V light to determine their base pair using 1500 bp DNA ladder as a standard.

\section{RESULT AND DISCUSSION}

The detection of PMQR genes in the CREC isolates is as given in Table 3. The order of occurrences of the genes was: $a a c-\left(6^{\prime}\right)-\operatorname{Ib}-c r(87.5 \%)>q n r B(50.0 \%)>q n r S(37.5 \%)>o q x A B$ $(12.5 \%)>q n r A(0.0 \%)$. The patterns of existence of the genes detected were as shown in Table 4. $q n r B$ and $q n r S$ did not exist alone, but in combination with other genes; $a a c-\left(6^{\prime}\right)-I b-c r$ existed both alone and in combination with others; the most prevalent patterns of existence were aac- $\left(6^{\prime}\right)-I b-c r$ alone and $a a c-\left(6^{\prime}\right)-I b-c r+q n r B+q n r S$ at $25.0 \%$ each. The distribution of the genes in relation to the isolates, as presented in Table 5, shows that isolate No.

7 contained all the genes detected. Representative agarose gel electrophoresis is as shown for $q n r B$ (Plate 1), qnrS (Plate 2), $a a c-\left(6^{\prime}\right)-I b-c r$ (Plate 3) and oqx $\mathrm{AB}$ (Plate 4). 
European Journal of Biology and Biotechnology www.ejbio.org

TABLE 1: Primers and their expected amplicon sizes for detection of plasmid-mediated quinolone resistance genes in the Escherichia coli isolates

\begin{tabular}{|c|c|c|c|c|}
\hline $\mathbf{S} / \mathbf{N}$ & Target Genes & Sequence & $\begin{array}{l}\text { Amplicon } \\
\text { Size (bp) } \\
\end{array}$ & References \\
\hline \multirow[t]{2}{*}{1} & $q n r A(\mathrm{~F})$ & 5' - CAGCAAGAGGATTTCTCACG - 3' & 630 & [22] \\
\hline & $q n r A(\mathrm{R})$ & $5^{\prime}$ - AATCCGGCAGCACTATTACTC- 3 ' & & \\
\hline \multirow[t]{2}{*}{2} & $q n r B(\mathrm{~F})$ & 5' - GGCTGTCAGTTCTATGATCG - 3' & 488 & [22] \\
\hline & $q n r B(\mathrm{R})$ & 5'- GAGCAACGATGCCTGGTAG - 3 & & \\
\hline 3 & $\begin{array}{l}q \operatorname{trS}(\mathrm{F}) \\
\operatorname{qn} r S(\mathrm{R})\end{array}$ & $\begin{array}{l}5^{\prime} \text { - GCAAGTTCATTGAACAGGGT- } 3^{\prime} \\
5^{\prime} \text {-TCTAAACCGTCGAGTCGGG- }\end{array}$ & 428 & {$[23]$} \\
\hline 4 & $\begin{array}{l}\operatorname{oq} x A B(\mathrm{~F}) \\
\operatorname{oq} x A B(\mathrm{R})\end{array}$ & $\begin{array}{l}5^{\prime} \text { - CCGCACCGATAAATTAGTCC- } 3^{\prime} \\
5^{\prime}-\text { GGCGAGGTTTTGATAGTGGA- } 3 \text { ' }\end{array}$ & 313 & {$[22]$} \\
\hline 5 & $\begin{array}{l}a a c-\left(6^{\prime}\right)-\operatorname{Ib}-c r(\mathrm{~F}) \\
a a c-\left(6^{\prime}\right)-\operatorname{Ib}-c r(\mathrm{R})\end{array}$ & $\begin{array}{l}\text { 5'-TTGGAAGCGGGGACGGAM- 3' } \\
\text { 5'-ACACGGCTGGACCATA- 3' }^{\prime}\end{array}$ & 260 & {$[24]$} \\
\hline
\end{tabular}

TABLE 2: Antimicrobial Resistance Pattern of ciprofloxacin-resistant Escherichia coli from urine of patients with suspected urinary tract infections attending Garki Hospital, Abuja Nigeria

\begin{tabular}{ll}
\hline \multicolumn{1}{c}{ Antimicrobial Resistance Pattern } & No. of Isolates \\
\hline AMC,S,CTX,CAZ,FOX,IPM,CIP,AMP & 1 \\
AMC,S,CTX,CAZ,FOX,CIP,AMP & 1 \\
AMC,S,SXT,FOX,CN,CIP,AMP & 1 \\
AMC,S,SXT,CTX,CAZ,FOX,CN,IPM,CIP,AMP & 1 \\
S,SXT,CTX,CAZ,FOX,CIP,AMP & 1 \\
S,FOX,CN,CIP,AMP & 1 \\
S,SXT,CTX,CAZ,CIP,AMP & 1 \\
CTX,CN,CIP,AMP & 1 \\
TOTAL & $\mathbf{8}$
\end{tabular}

No. $=$ Number AMC $=$ Amoxicillin/Clavulanic Acid AMP $=$ Ampicillin $;$ CTX $=$ Cefotaxime $;$ CAZ $=$ Ceftazidime $;$ CIP $=$ Ciprofloxacin $;$ FOX= Cefoxitin; CN=Gentamicin; IPM= Imipenem; S= Streptomycin; SXT= Sulphamethoxazole/Trimethoprim [20].

TABLE 3: Occurrence of plasmid-mediated quinolone resistance genes in ciprofloxacin-resistant Escherichia coli from urine of patients attending Garki Hospital Abuja, Nigeria

\begin{tabular}{cc}
\hline Quinolone Resistance Genes & No. $(\%)$ of Escherichia coli $(\mathbf{n}=8)$ \\
\hline QnrA & $0(0.0)$ \\
$Q n r B$ & $4(50.0)$ \\
$Q n r S$ & $3(37.5)$ \\
OqxAB & $1(12.5)$ \\
$a a c-\left(6^{\prime}\right)-I b-c r$ & $7(87.5)$ \\
\hline
\end{tabular}

TABLE 4: Pattern of existence of the plasmid-mediated quinolone resistance genes in the ciprofloxacin-resistant Escherichia coli from urine of patients attending Garki Hospital, Abuja, Nigeria

\begin{tabular}{lc}
\multicolumn{2}{c}{$\begin{array}{c}\text { pe of the plasmid-mediated quinolone resistance genes in the ciprofloxacin-resistant } \\
\text { patients attending Garki Hospital, Abuja, Nigeria }\end{array}$} \\
\hline \multicolumn{1}{c}{ Quinolone Resistance Genes } & No. (\%) of Escherichia coli $(\mathbf{n}=\mathbf{8})$ \\
\hline$q n r B$ alone & $1(12.5)$ \\
$q n r S$ alone & $0(0.0)$ \\
oqxAB alone & $0(0.0)$ \\
$a a c-\left(6^{\prime}\right)-I b-c r$ alone & $2(25.0)$ \\
$a a c-\left(6^{\prime}\right)-I b-c r+q n r B$ & $1(12.5)$ \\
$a a c-\left(6^{\prime}\right)-I b-c r+q n r S$ & $1(12.5)$ \\
$a a c-\left(6^{\prime}\right)-I b-c r+q n r B+q n r S$ & $2(25.0)$ \\
$a a c-\left(6^{\prime}\right)-I b-c r+q n r B+q n r S+o q x A B$ & $1(12.5 .0)$ \\
\hline
\end{tabular}

No. $=$ Number 
European Journal of Biology and Biotechnology www.ejbio.org

TABLE 5: Distribution of plasmid-mediated quinolone resistance genes in ciprofloxacin-resistant Escherichia coli from urine of patients in Garki Hospital

\begin{tabular}{|c|c|c|c|c|c|c|c|}
\hline \multirow{3}{*}{$\begin{array}{c}\text { Isola } \\
\text { te }\end{array}$} & \multirow{3}{*}{ Antimicrobial Resistance Pattern } & \multicolumn{5}{|c|}{ Abuja, Nigeria } & \multirow{3}{*}{ PMQR Genes } \\
\hline & & \multicolumn{5}{|c|}{ Presence of PMQR Genes } & \\
\hline & & qnrA & $q n r B$ & QnrS & $o q x A B$ & $a a c-\left(6^{\prime}\right)-I b-c r$ & \\
\hline 1. & AMC,S,CTX,CAZ,FOX,IPM,CIP,AMP & - & + & - & - & + & $a a c-\left(6^{\prime}\right)-I b-c r+q n r B$ \\
\hline 2. & AMC,S,CTX,CAZ,FOX,CIP,AMP & - & - & - & - & + & $a a c-\left(6^{\prime}\right)-I b-c r$ \\
\hline 3. & AMC,S,SXT,FOX,CN,CIP,AMP & - & - & + & - & + & $a a c-\left(6^{\prime}\right)-I b-c r+q n r S$ \\
\hline 4. & $\begin{array}{l}\text { AMC,S,SXT,CTX,CAZ,FOX,CN,IPM, } \\
\text { CIP,AMP }\end{array}$ & - & + & - & - & - & $q n r B$ \\
\hline 5. & S,SXT,CTX,CAZ,FOX,CIP,AMP & - & - & - & - & + & $a a c-\left(6^{\prime}\right)-I b-c r$ \\
\hline 6. & S,FOX,CN,CIP,AMP & - & + & + & - & + & $a a c-\left(6^{\prime}\right)-I b-c r+q n r B+q n r S$ \\
\hline 7. & S,SXT,CTX,CAZ,CIP,AMP & - & + & + & + & + & $\begin{array}{l}a a c-\left(6^{\prime}\right)-I b-c r+q n r B+q n r S+ \\
o q x A B\end{array}$ \\
\hline 8. & CTX,CN,CIP,AMP & - & + & + & - & + & $a a c-\left(6^{\prime}\right)-I b-c r+q n r B+q n r S$ \\
\hline
\end{tabular}

$\mathrm{AMC}=$ Amoxicillin/Clavulanic Acid; $\mathrm{AMP}=$ Ampicillin $; \mathrm{CTX}=$ Cefotaxime; $\mathrm{CAZ}=$ Ceftazidime $\mathrm{CIP}=\mathrm{Ciprofloxacin} ; \mathrm{FOX}=\mathrm{Cefoxitin} ; \mathrm{CN}=\mathrm{Gentamicin} ;$ IPM= Imipenem; S= Streptomycin; SXT= Sulphamethoxazole/Trimethoprim

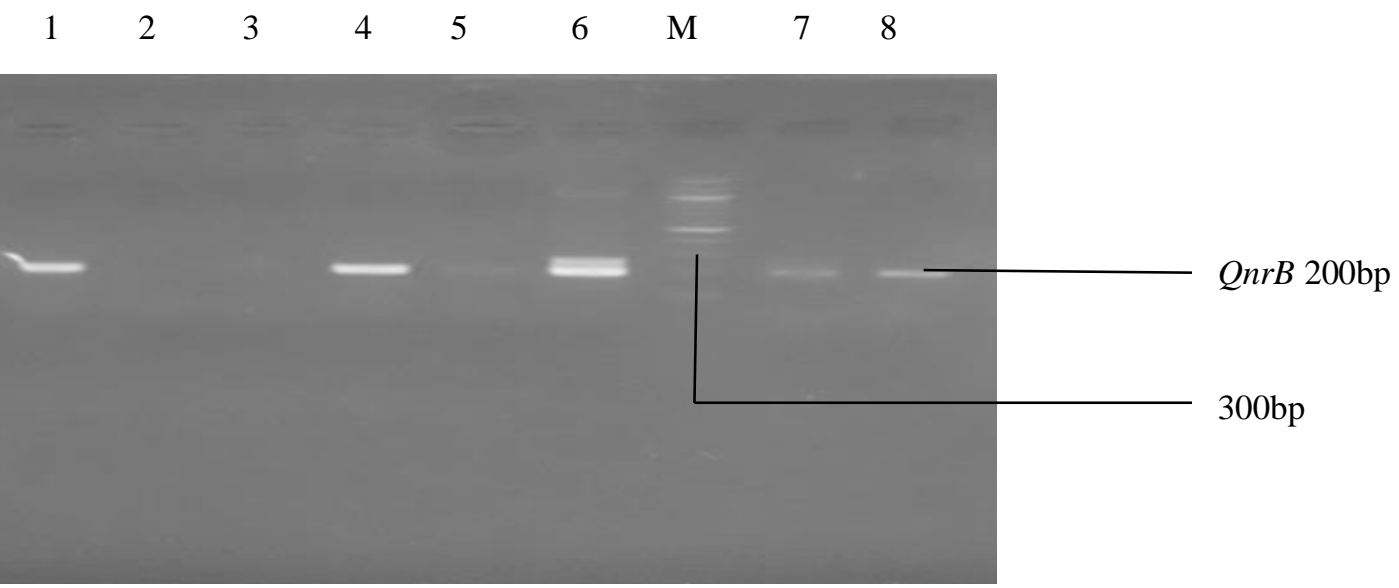

Plate 1: Agarose gel electrophoresis of the amplified $q n r \mathrm{~B}$ genes from the $E$. coli isolates. Lanes 1, 4, 5, 6, 7 and 8 represent the qnrB band, Lane $\mathrm{M}$ represents the $1500 \mathrm{bp}$ molecular ladder, while other lanes show no bands.

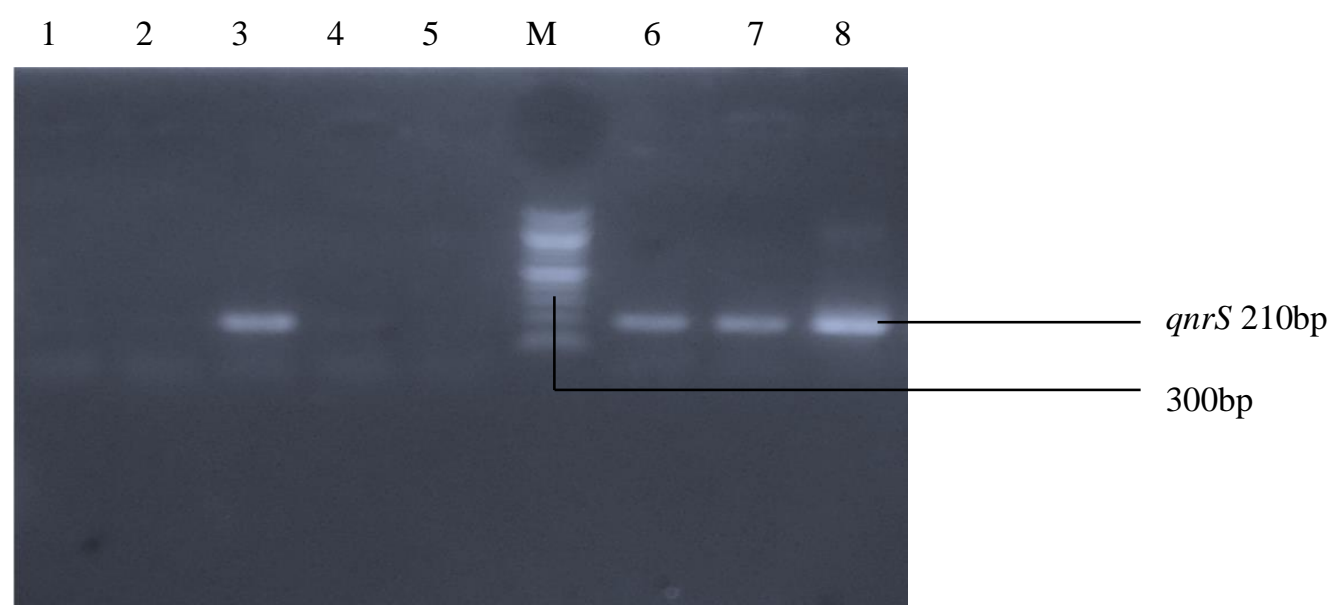

Plate 2: Agarose gel electrophoresis of the amplified $q n r \mathrm{~S}$ genes from the E. coli isolates. Lanes 3, 4, 6, 7 and 8 represent the $q n r S$ band, Lane $\mathrm{M}$ represents the $1500 \mathrm{bp}$ molecular ladder, while other lanes show no bands. 


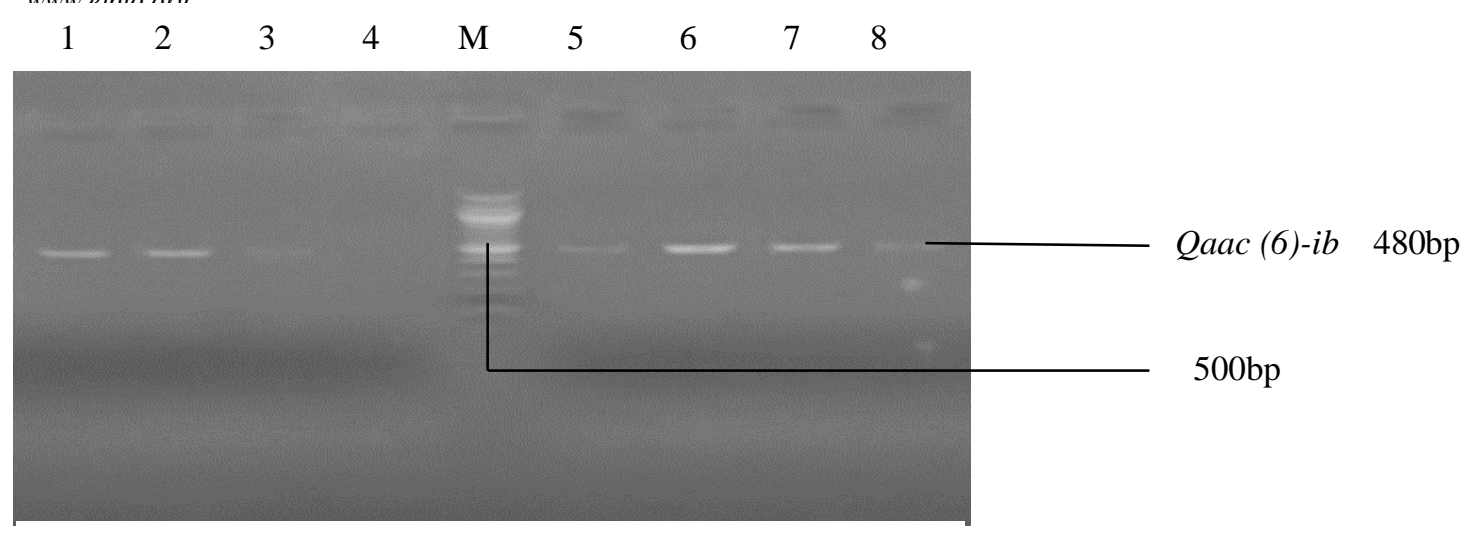

Plate 3: Agarose gel electrophoresis of the amplified aac (6')-Ib-cr genes from the $E$. coli isolates. Lanes 1, 2, 3, 5, 6, 7 and 8 represent the aac- $\left(6^{\prime}\right)-\mathrm{Ib}-\mathrm{cr}$ band, Lane $\mathrm{M}$ represents the $1500 \mathrm{bp}$ molecular ladder, while other lanes show no bands.

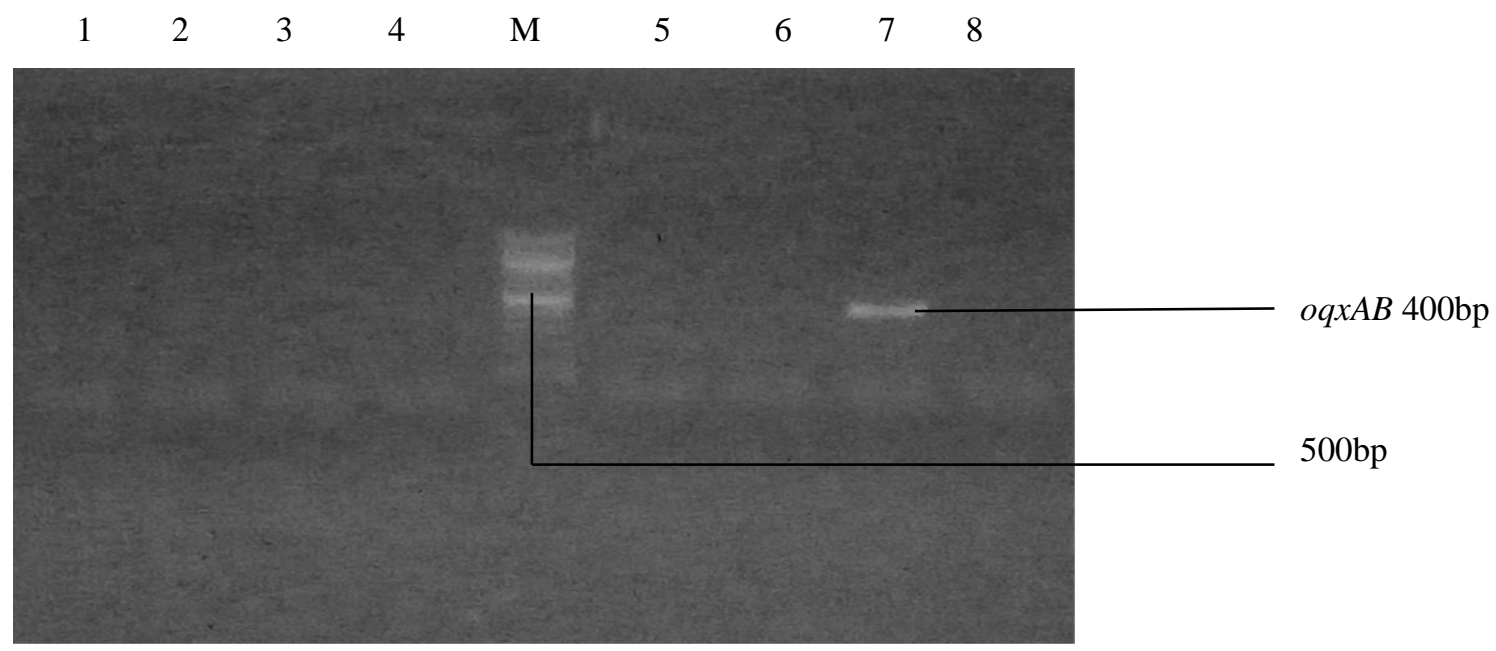

Plate 4: Agarose gel electrophoresis of the amplified $o q x A B$ genes from the $E$. coli isolates. Lanes 7 represent the oqxAB band, Lane M represents the $1500 \mathrm{bp}$ molecular ladder, while other lanes show no bands.

Fluoroquinolones are now listed by the WHO as Critically Important Antimicrobials (CIA) for the treatment of human infections [25]. Ciprofloxacin is a fluoroquinolone with a range of indications, including urinary tract infections frequently caused by E. coli [3], [26], [27]. In the decade after its introduction all resistance reported in Enterobacteriaceae was associated with chromosomal mutations [28]. Recently, PMQR has become a frequent component of clinical resistance [3], [29]. Antimicrobial resistance to FQs mediated either by chromosomal mutations or transmissible plasmids is thus a major public health challenge. This study investigated the presence of PMQR genes in ciprofloxacinresistant E. coli isolated from suspected UTI patients attending Garki Hospital, Abuja, Nigeria.

The detection of $q n r B, q n r S, o q x A B$ and $a a c-\left(6^{\prime}\right)-I b-c r$ PMQR genes in the CRECs from urine of suspected UTI patients is in tandem with other studies which have reported different prevalences of PMQR genes in CRECs from urine of humans [30]-[33]. Plasmid-mediated quinolone resistance genes are known to mediate transmissible resistance to fluoroquinolones [9], [10], [34].

The observed higher prevalence of $a a c-\left(6^{\prime}\right)-I b-c r$ gene (87.5\%) compared with any of the $q n r$ PMQR genes is not surprising as it is often more common than qnr genes [2], [22], [35]-[38]. Our study has also shown a higher prevalence of $q n r B(50.0 \%)$ compared with $q n r S(37.5 \%)$ in agreement with already known fact that of the $q n r$ varieties, $q n r B$ seems somewhat more common than $q n r A$ or $q n r S$, which are more common than $q n r D$ [39]. The detection of $o q x A B$ gene in $E$. coli is not new as it has been found on plasmids in clinical isolates of $E$. coli in other studies [40]-[42]. The $O q x A B$ multidrug resistance mechanism was initially identified from $E$. coli strains recovered from swine manure [43]. The observed low prevalence of the oqxAB gene $(12.5 \%)$ is in contrast with a study in Iran by [43] which reported a high prevalence of $69.1 \%$.

The presence of qnr genes in clinically relevant species of both gram-positive and gram-negative bacteria may foster quinolone resistance development as several classes of $q n r$ genes have been identified that reduce susceptibility to fluoroquinolones [29], [44]. The Qnr proteins bind to DNA gyrase and topoisomerase IV and protect the enzymes from inhibition by quinolones [45], [46]. Although plasmidborne $q n r$ genes contribute to resistance development, the presence of a plasmid-borne $q n r$ gene alone is insufficient to confer clinical resistance [47].

The presence of the $a a c\left(6^{\prime}\right)-I b-c r$ gene in the isolates suggests its possible involvement in the ciprofloxacin resistance observed in the isolate containing the gene. This gene has been implicated in FQ resistance in E. coli in 
Nigeria and a few other African countries. The association of $a a c\left(6^{\prime}\right)-I b-c r$ gene with ESBL CTXM-15 has been reported [35], [48]-[51], making its detection of serious clinical importance. The gene encodes a variant of the common aminoglycoside acetyltransferase, $\mathrm{AAC}\left(6^{\prime}\right)$-Ib-cr, which catalyzes the acetylation of quinolones with an appropriate amino nitrogen target (such as ciprofloxacin and norfloxacin) [52].

The oq $A B$ gene detected in the isolates contributed to the ciprofloxacin resistance as the gene mediates enhanced efflux by encoding the efflux pump OqxAB [10]. The detection of $o q x A B$ gene is significant clinically as linkage of the gene with genes for the extended beta-lactamase CTX-M-14 and other plasmid-mediated CTX-M alleles has been noted [53].

\section{CONCLUSION}

The CREC harbored PMQR genes with occurrences in the order: $a a c-\left(6^{\prime}\right)-\operatorname{Ib}-c r(87.5 \%)>q n r B(50.0 \%)>q n r S(37.5 \%)$ $>\operatorname{oqx} A B(12.5 \%)$. qnrA was not detected in any of the isolates. $q n r B$ and $q n r S$ did not exist alone, but in combination with other genes; $a a c-\left(6^{\prime}\right)-I b-c r$ existed both alone and in combination with others; the most prevalent patterns of existence were $a a c-\left(6^{\prime}\right)-I b-c r$ alone and $a a c-\left(6^{\prime}\right)$ $I b-c r+q n r B+q n r S$ at $25.0 \%$ each. The occurrence of $q n r B$, $q n r S$, oq $x A B$ and $a a c-\left(6^{\prime}\right)-I b-c r$ PMQR genes observed in the CREC isolates is indication that these genes may have contributed to the resistance by the isolates to ciprofloxacin. We thus recommend prudent use of fluoroquinolones both in human and veterinary medicine since there is already established strong correlation between the consumption and an increase in the resistance.

\section{REFERENCES}

[1] R. M. Akova, F. Baquero, J. Carlet, M. Cavaleri, S. Coenen, J. Cohen, D. Findlay, I. Gyssens, O. E. Heuer, G. Kahlmeter, H. Kruse, R. Laxminarayan, E. Liébana, L. López-Cerero, A. MacGowan, M. Martins, J. Rodríguez-Baño, J. M. Rolain, C. Segovia, B. Sigauque, E. Tacconelli, E. Wellington, J. Vila, Corrigendum to "The global Threat of Antimicrobial Resistance: Science for Intervention" New Microbes New Infect, 2015, 6: pp 22-29

[2] J. Ma, Z. Zeng, Z. Chen, X. Xu, X. Wang, Y. Deng, D. Lü, L. Huang, Y. Zhang, J. Liu, High Prevalence of Plasmid-mediated Quinolone Resistance Determinants $q n r, a a c\left(6^{\prime}\right)-I b-c r$ and qepA among ceftiofur-resistant Enterobacteriaceae isolates from companion and food-producing animals. Antimicrob Agents Chemother, 2009, 53: pp 519-524.

[3] L. S. Redgrave, S. B. Sutton, M. A. Webber, L. J. Piddock. Fluoroquinolone Resistance: Mechanisms, Impact on Bacteria, and Role in Evolutionary Success. Trends Microbiol, 2014, 22: pp 438445.

[4] K. J. Aldred, R. J. Kerns, N. Osheroff. Biochemistry Mar 18; 2014, 53(10): pp 1565-1574.

[5] M. Röderova, D. Halova, I. Papousek, M. Dolejska, M. Masarikova, V. Hanulik, V. Pudova, P. Broz, M. Htoutou-Sedlakova, P. Sauer, J. Bardon, A. Cizek, M. Kolar, I. Literak, Characteristics of Quinolone Resistance in Escherichia coli Isolates from Humans, Animals, and the Environment in the Czech Republic. Front Microbiol, 2016, 7: pp 2147.

[6] J. C. Yeh, D. Y. Lo, S. K. Chang, C. C. Chou, H. C. Kuo, Prevalence of Plasmid-mediated Quinolone Resistance in Escherichia coli Isolated from Diseased Animals in Taiwan. J Vet Med Sci, 2017, 79(4): pp 730735 .

[7] G. A. Jacoby, Mechanisms of Resistance to Quinolones. Clin Infect Dis, 2005, 41(2): pp 120-126.

[8] S. J. Osei, D. G. Amoako, Genomic and Phenotypic Characterisation of Fluoroquinolone Resistance Mechanisms in Enterobacteriaceae in Durban, South Africa. PLoS ONE, 2017, 12(6)
[9] R. Zhang, T. Ichijo, Y. L. Huang, J. C. Cai, H. W. Zhou, H. Yamaguchi, High Prevalence of $q n r$ and $a a c\left(6^{\prime}\right)-\mathrm{Ib}$-cr Genes in Both Water-Borne Environmental Bacteria and Clinical Isolates of Citrobacter freundii in China. Microbes Enviroment; 2012, 27: pp 158-163.

[10] G. A. Jacoby, J. Strahilevitz, D. C. Hooper, Plasmid-mediated quinolone resistance. Microbiol. Spectr. 2014, 2(2).

[11] M. Wang, J. H. Tran, G.A. Jacoby, Y. Zhang, F. Wang, D. C. Hooper, Plasmid-mediated Quinolone Resistance in Clinical Isolates of Escherichia coli from Shanghai, China. Antimicrob Agents Chemother, 2003, 47(7): pp 2242-8.

[12] V. Cattoir, P. Nordmann, J. Silva-Sanchez, P. Espinal, L. Poirel, ISEcp 1-mediated Transposition of $q n r B$-like Gene in Escherichia coli. Antimicrob Agents Chemother, 2008, 52, pp 2929-2932.

[13] S. S. Namboodiri, J. A. Opintan, R. S. Lijek, M. J. Newman, I. N. Okeke, Quinolone resistance in Escherichia coli from Accra, Ghana. BMC Microbiology, 2011, 11: pp 44.

[14] D. Tausova, M. Dolejska, A. Cizek, L. Hanusova, J. Hrusakova, O. Svoboda, G. Camlik, I. Literak, Escherichia coli with Extendedspectrum ß-lactamase and plasmid-mediated quinolone Resistance Genes in Great Cormorants and Mallards in Central Europe. J Antimicrob Chemother, 2012, 67: pp 1103-1107.

[15] A. Bartoloni, L. Pallecchi, E. Riccobono, A. Mantella, D. Magnelli, T. Di Maggio, A. L. Villagran, Y. Lara, C. Saavedra, M. Strohmeyer, F. Bartalesi, C. Trigoso, G. M. Rossolini, Relentless Increase of Resistance to Fluoroquinolones and Expanded-Spectrum Cephalosporins in Escherichia coli: 20 years of Surveillance in Resource-limited Settings from Latin America. Clin Microbiol Infect, 2013, 19, pp 356-361.

[16] C. H. Kim, E. H. Choi, J. Y. Sung, C. E. Oh, H. B. Kim, E. C. Kim, H. J. Lee, Prevalence of Plasmid-Mediated Quinolone Resistance Genes and Ciprofloxacin Resistance in Pediatric Bloodstream Isolates of Enterobacteriaceae over a 9-year period. Jpn J Infect Dis, 2013, 66 pp $151-154$.

[17] I. Jamborova, M. Dolejska, J. Vojtech, S. Guenther, R. Uricariu, J. Drozdowska, I. Papousek, K. Pasekova, W. Meissner, J. Hordowski, A. Cizek, I. Literaka. Plasmid-Mediated Resistance to Cephalosporins and Fluoroquinolones in Various Escherichia coli Sequence Types Isolated from Rooks Wintering in Europe. Applied and Environmental Microbiology, 2015, 81(2); pp 648-657.

[18] D. Fortini, K. Fashae, A. Garc1'a-Ferna'ndez, L. Villa, A. Carattoli, Plasmid-mediated Quinolone Resistance and -lactamases in Escherichia coli from Healthy Animals from Nigeria. J Antimicrob Chemother; 2011, 66: pp 1269-1272.

[19] E. T. Sumrall, E. B. Gallo, A. O. Aboderin, A. Lamikanra, I. N. Okeke, Dissemination of the Transmissible Quinolone-Resistance Gene $q n r S 1$ by IncX Plasmids in Nigeria. PLoS ONE, 2014, 9(10): pp $1-10$.

[20] M. O. Eghieye, S. M. Jodi, B. E. Bassey, I. H. Nkene, R. H. Abimiku, Y. B. Ngwai, Antimicrobial Resistance Profile of Escherichia coli Isolated from Urine of Patients in Selected General Hospitals in Abuja Municipal, Nigeria. Asian Journal of Advanced Research and Reports 2018, 2(2): pp 1-10.

[21] L. A. Porteus, J. L. Armstrong, R. J. Seider, L. S. Watrud, An effective Method to extract DNA from Environmental Samples for Polymerase Chain Reaction Amplification and DNA Finger Print Analysis. Current microbiology, 1994, 29: pp 301-307.

[22] H. Ciesielczuk, M. Hornsey, V. Choi, N. Woodford, D. W. Wareham, Development and Evaluation of a Multiplex PCR for Eight Plasmidmediated Quinolone-resistance Determinants, 2013, 62(12): pp 18231827.

[23] V. Cattoir, L. Poirel, V. Rotimi, C. J. Soussy, P. Nordmann, Multiplex PCR for Detection of Plasmid-mediated Quinolone Resistance qnr Genes in ESBL-producing Enterobacterial Isolates. J Antimicrob Chemother, 2007, 60; pp 394-397.

[24] D. W. Wareham, I. Umoren, P. Khanna, N. C. Gordon, Allele-specific Polymerase Chain Reaction (PCR) for Rapid Detection of the aac(69)Ib-cr Quinolone Resistance Gene. Int J Antimicrob Agents, 2010, 36 pp 476-477.

[25] WHO. World Health Organization, Critically Important Antimicrobials for Human Medicine. Clin. Infect. Dis, 2017, 48.

[26] W. Castro, M. Navarro, C. Biot, Medicinal Potential of Ciprofloxacin and its Derivatives. Future Med Chem, 2013, 5: pp 81-96.

[27] WHO. Antimicrobial Resistance: Global Report on Surveillance 2014 Geneva, Switzerland: WHO, 2014

[28] D. C. Hooper, Mechanisms of action and resistance of older and newer fluoroquinolones. Clin Infect Dis, 2000, 31(2): pp 24-8.

[29] J. M. Rodriguez-Martinez, J. Machuca, M. E. Cano, Plasmid-mediated Quinolone Resistance: Drug Resist Update; 2016, 29: pp 13-29.

[30] H. Nazik, B. Bektöre, B. Öngen, M. İlktac,, M. Özyurt, N. Kuvat, O. Baylan, H. Keküllüoğlu, T. Haznedaroğlu, F. H. Keleşoğlu, Plasmid- 
Mediated Quinolone Resistance Genes in Escherichia coli Urinary Isolates from Two Teaching Hospitals in Turkey: Coexistence of TEM, SHV, CTX-M and VEB-1 Type $\beta$-lactamases. Tropical Journal of Pharmaceutical Research, 2011, 10(3): pp. 325-333

[31] W. Pasom, A. Chanawong, A. Lulitanond, C. Wilailuckana, S. Kenprom, P. Puang-Ngern, Plasmid-mediated Quinolone Resistance Genes, $a a c\left(6^{\prime}\right)-I b-c r, q n r S$, $q n r B$, and $q n r A$, in Urinary Isolates of Escherichia coli and Klebsiella pneumoniae at a Teaching Hospital, Thailand. Jpn J Infect Dis, 2013, 66(5): pp 428-32.

[32] C. Inwezerua, N. Mendonça, V. Calhau, S. Domingues, O. E. Adeleke, G. J. Da Silva, Occurrence of Extended-Spectrum beta-lactamases in Human and Bovine Isolates of Escherichia coli from Oyo state, Nigeria. J Infect Dev Ctries, 2014, 8(6): pp 774-779.

[33] L. Zhao, J. Zhang, B. Zheng, Z. Wei, P. Shen, S. Li, L. Li, Y. Xiao, Molecular Epidemiology and Genetic Diversity of FluoroquinoloneResistant Escherichia coli Isolates from Patients with CommunityOnset Infections in 30 Chinese County Hospitals. Journal of Clinical Microbiology, 2015, 53 (3): pp 766-770.

[34] J. M. Blair, M. A. Webber, A. J. Baylay, D. O. Ogbolu, L. J. Piddock, Molecular Mechanisms of Antibiotic Resistance. Nat. Rev. Microbiol. 2015, 13; pp 42-51.

[35] J. D. Pitout, Y. Wei, D. L. Church, D. B. Gregson, Surveillance for plasmid-mediated quinolone resistance determinants in Enterobacteriaceae within the Calgary Health Region, Canada: the Emergence of aac $\left(6^{\prime}\right)-I b-c r . J$ Antimicrob Chemother, 2008, 61: pp 999-1002.

[36] E. Ruiz, Y. Saenz, M. Zarazaga, R. Rocha-Gracia, L. MartinezMartinez, G. Arlet, C. Torres, qnr, aac $\left(6^{\prime}\right)-I b-c r$ and qepA genes in Escherichia coli and Klebsiella spp.: Genetic Environments and Plasmid and Chromosomal Location. J Antimicrob Chemother, 2012, 67: pp 886-897.

[37] C. H. Park, A. Robicsek, G. H. Jacoby, D. Sahm, D. C. Hooper, Prevalence in the United States of $a a c\left(6^{\prime}\right) I b-c r$ Encoding a Ciprofloxacin-Modifying Enzyme. Antimicrob Agents Chemother, 2006, 50: pp 3953-3955.

[38] J. Yang, Y. Luo, J. Li, Y. Ma, C. Hu, S. Jin, L. Ye, S. Cui, Characterization of clinical Escherichia coli Isolates from China Containing Transferable Quinolone Resistance Determinants. J Antimicrob Chemother; 2010, 65: pp 453-459.

[39] L. Poirel, V. Cattoir, P. Nordmann, Plasmid-mediated Quinolone Resistance; Interactions Between Human, Animal, and Environmental Ecologies. Front. Microbiol., 2012, 3: pp 24.

[40] A. Norman, L. H. Hansen, Q. She, S. J. Sørensen, Nucleotide Sequence of pOLA52: a Conjugative IncX1 Plasmid from Escherichia coli Which Enables Biofilm Formation and Multidrug Efflux. Plasmid., 2008, 60: pp 59-74

[41] H. B. Kim, M. Wang, C. H. Park, E. C. Kim, G. H. Jacoby, D. C. Hooper, $o q x A B$ Encoding a Multidrug Efflux Pump in Human Clinical Isolates of Enterobacteriaceae. Antimicrob Agents Chemother., 2009, 53: pp 3582-3584.

[42] J. Zhao, Z. Chen, S. Chen, Y. Deng, Y. Liu, W. Tian, X. Huang, C. Wu, Y. Sun, Z. Zeng, J. H. Liu, Prevalence and Dissemination of oqxAB in Escherichia coli Isolates from Animals, Farmworkers, and the Environment. Antimicrob Agents Chemother; 2010, 54: pp 4219-4224.

[43] L. H. Hansen, S. J. Sørensen, H. S. Jørgensen, L. B. Jensen, The prevalence of the OqxAB Multidrug Efflux Pump Amongst olaquindox-resistant Escherichia coli in pigs. Microb. Drug Resist. 2005, 11: pp 378-382.

[44] D. C. Hooper, G. H. Jacoby. Mechanisms of Drug Resistance: Quinolone Resistance. AnnNYAcadSci 1354: pp 12-31.

[45] J. H. Tran, G. A. Jacoby, D. C. Hooper, Interaction of the plasmidencoded quinolone resistance protein QnrA with Escherichia coli topoisomerase IV. Antimicrob Agents Chemother; 2005, 49: pp 3050-

[46] J. H. Tran, G. A. Jacoby, D. C. Hooper, Interaction of the plasmidencoded quinolone resistance protein Qnr with Escherichia coli DNA Gyrase. Antimicrob Agents Chemother; 2005b, 49: pp 118-25.

[47] L. Garoff, K. Yadav, D. Hughes, Increased Expression of Qnr is Sufficient to Confer Clinical Resistance to Ciprofloxacin in Escherichia coli. Journal of Antimicrobial Chemotherapy, 2018 73(2); pp 348-352,

[48] G. L. Jones, R. E. Warren, S. J. Skidmore, V. A. Davies, T. Gibreel, M. Upton, Prevalence and Distribution of Plasmid-Mediated Quinolone Resistance Genes in Clinical Isolates of Escherichia coli Lacking Extended-Spectrum ß-lactamases. J Antimicrob Chemother; 2008 , 62:1245-1251

[49] P. J. Baudry, K. Nichol, M. DeCorby, P. Lagace-Wiens, E. Olivier, D. Boyd, M. R. Mulvey, D. J. Hoban, G. G. Zhanel, Mechanisms of resistance and mobility among multidrug-resistant CTX-M-producing Escherichia coli from Canadian intensive care units: the 1st report of
QepA in North America. Diagn Microbiol Infect Dis; 2009, 63: pp 319326.

[50] E. Literacka, B. Bedenic, A. Baraniak, J. Fiett, M. Tonkic, I. JajicBencic, M. Gniadkowski, blaCTX-M genes in Escherichia coli strains from Croatian Hospitals are Located in New (blaCTX-M-3a) and Widely Spread (blaCTX-M-3a and blaCTX-M-15) Genetic structures. Antimicrob Agents Chemother.; 2009, 53: pp 1630-1635.

[51] M. Perilli, C. Forcella, G. Celenza, P. Frascaria, B. Segatore, C. Pellegrini, G. Amicosante, Evidence for $q n r B 1$ and $a a c\left(6^{\prime}\right)-I b-c r$ in CTX-M-15-producing Uropathogenic Enterobacteriaceae in an Italian Teaching Hospital. Diagn Microbiol Infect Dis; 64: pp 90-93.

[52] S. Sabtcheva, M. Kaku, T. Saga, Y. Ishii, T. Kantardjiev, High Prevalence of the $a a c\left(6^{\prime}\right)-I b-c r$ Gene and its Dissemination Among Enterobacteriaceae Isolates by CTX-M-15 Plasmids in Bulgaria. Antimicrob Agents Chemother; 2009, 53: pp 335-336.

[53] B. T. Liu, Q. E. Yang, L. Li, J. Sun, X. P. Liao, L. X. Fang, S. S. Yang, H. Deng, Y. H. Liu, Dissemination and Characterization of Plasmids Carrying oqxAB-bla CTX-M genes in Escherichia coli Isolates from Food-Producing Animals. PLoS One.; 2013, 8. 